\title{
Structured Acquaint of Mobile Applications for Secured Travel on Indian Roads
}

\author{
N.Sasikala, Gul Mohamed Rasitha Banu, M. Ravithammal
}

\begin{abstract}
In our earlier days all of us love to travel on roads. The avenue trips had been a large part of our formative years and several our favorite memories. They had been an extraordinary way to spend time as a circle of relatives together, tour on a budget, and see a whole lot of the countryside. But Now a days travelling on roads is not so easy and safety. Current Indian roads and driving conditions are also a topic of discussion, and there is no reliable statistics on how many people die or are injured as a result of road rage. In this technological world we must think how to make it possible for us to have a pleasant and peaceful travel. Mobile applications are ready to help us to make our travel with happiness and peace. In this survey, we can have a comparative study of how these mobile applications helps to all the drivers in the world to have their safety travel. The mobile apps providing the data like Traffic data collection, travel information, route planning, ridesharing, etc. There are some mobile apps like Waze, Google map, Infix for traffic information which makes your travel easy and on time. Some other mobile apps like AxiKit, Collision Call., SOSmart, helps for car crashes and emergencies. INRIX parkme, Spot Angels, Audible are the apps helps to find the right places for their customs and road conditions.
\end{abstract}

Keywords: Road conditions, RTA, Safety, Mobile App, safety travel, Waze, Infix, Axikit, SOSmart, Spot angels.

\section{INTRODUCTION}

Now a days the Road Accidents are very common in large cities where there are many modes of transports and roads are available. We hear about them and read about them almost every day in the newspapers. Such accidents cause loss of life and material. They are caused by the negligence and ignorance of the drivers and the negligence of the traffic rules. India, a high-growing country with an expanding economy, has one of the highest growth levels of motorization accompanied by rapid expansion of road networks and population growth. According to the facts the Traffic collision-associated fatalities expanded from 13 consistent with hour in 2008 to 14 per hour in 2009. More than $40 \%$ of these casualties are connected to bikes and trucks. The maximum collision-prone time on Indian roads is for the duration of the afternoon and nighttime height hour. statistics the highest avenue collisions for a decade and its capital Chennai has extra collisions than any other city in India [1].In this paper, we discussed about the causes for road accidents and a preventive measures to avoid these accidents

Revised Manuscript Received on December 5, 2019.

Dr.N. Sasikala, Assistant Professor, Department of Health Informatics, FPHTM, Jazan University, KSA.

Dr.Gul Mohamed Rasitha Banu, Assistant Professor, Department of Health Informatics, FPHTM, Jazan University, KSA.

Dr.M. Ravithammal, Assistant Professor, Department of Mathematics, The Quaide Milleth College for Men, Chennai - 600100, Tamil Nadu, India.

and a comparative study about the different apps used for this travelling time and accident preventions.

This paper is organized as follows: Section II describes the causes of road accidents in Indian roads, Section III presents various preventive measures that are utilized in our system, Section IV describes the services of mobile apps in various way to protect our beloved ones and friends from their travelling times and some time it helps to save their lives from their accidents. I hope this paper will create an awareness for the smart phone users by let them know about different apps which helps them to have a good time management by knowing their traffic updates to avoid wasting of their precious time. It also guides for knowing the details of new places in their travels and helps to protect them when they need medications while accidents.

\section{RATIONALES OF ROAD ACCIDENTS IN INDIA}

Road Accident is the leading cause of death for people aged 15-29, according to World Health Organization (WHO). Road traffic incidents were predicted to be among the top-leading cause of death by 2030. [ 2-3]. Several Risk factors are there which causes these accidents. We can categorize these as human risk factors and environmental factors. The human risk factors are such as Driver's Tiredness, sleepiness, younger age (15-29 years), male sex, inadequate use of helmets and safety belts, medical conditions (sudden illness, myocardial infarction, impaired vision), psychological factors (risk-taking, impulsive-ness), defective judgment, delayed decisions, aggressiveness, poor perception, family dysfunction, and distraction(using mobile phones) also are responsible human factors in RTA. [5,6] Environmental risk factors are the factors which are related to the roads like defective and narrow roads, defective layout of crossroads, poor lighting, and lack of familiarity, poor construction, bad design etc.

\section{VIOLATIONS OF ROAD SAFETY RULES}

Since early 1980s, the position of human behavior has been identified in road visitors' accidents (RTA) [10,11]. During this time, maximum of the legal guidelines such as using helmets for millions of riders and seat belts for vehicles were enforced around the world [9].Such studies are conducted in numerous components of the planet as well as some cities of Asian nation too, however tutorial analysis alone is least seemingly to stop RTA [10,9]. Different Road protection campaigns and trainings have been suggested to bring trade in attitude for sustainable change in behavior of people by means of RTAs.[12,13,14].Educational programs could incorporate temperament troubles with the purpose of encouraging drivers to well

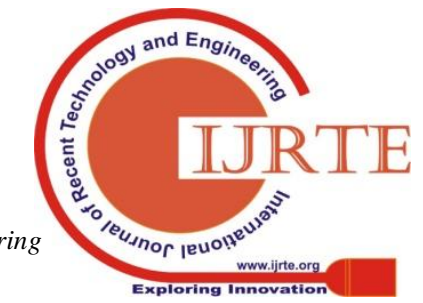


known the outcomes of sure tendencies and emotions that might place them et al. In threat for extreme RTAs. Similarly, to incorporate behavior evaluation of the driver's RTA suggested to include study materials in the school curriculum may have early and long-lasting effects. Having validating angle towards risky driving behaviors and not obtaining recommendation concerning risky driving from vital others will increase the probability of developing risky driving behavior.

\section{PREVENTIVE AND PROTECTIVE MEASURES}

There are many road accidents and deaths that can be prevented. Some of the preventive measures are outlined below briefly. The Well-maintained vehicles will reduce accidents with good breaks, lighting, tyres, etc. It is important to phase out older vehicles and highly polluting vehicles. With frequent relaying of road surfaces and road safety sign markings, road should be well maintained. Provide appropriate footpaths at intersections for pedestrians and pedestrian crossings. Provide separate lanes for cars that move slowly and quickly. Roads and junctions for good visibility should be wide and well-lit. With frequent relaying of road surfaces and road safety sign markings, road should be well maintained. $[4,6]$ We can use the mobile apps to prevent the accidents with its wide usages of different areas.

\section{MOBILE APPS FOR SAFETY TRAVEL}

Scientific Inventions and innovations are the key factors of unique growth of today's world. One of the prevention steps for this prior problem of accidents is utilizations of mobile apps. Mobile phones are an inevitable part of our lives today. For our erratic lives, mobile apps have proved a blessing. There are several mobile apps are providing their services in the best way.

\section{A.Traffic control App}

No one desires to be caught in traffic, which is why it is crucial to have a site visitors app to your smartphone. Whether you're visiting to work every day or making plans to hire a vehicle and drive in a high-traffic town or area, a visitor's app for your desires is probably to be available. Traffic capabilities are normally integrated into present navigation apps, providing real-time tour time and in-length estimates. These apps will help the drivers to change your route primarily based on real-time traffic, facts about accidents, construction, and police. Gives you an estimated traffic-based time of arrival. The more you use the app, the better it gets to know you, learn the paths and destinations you frequently use, as well as the hours you travel. The traffic control apps are WAZE, GOOGLE MAP, INRIX, MAPQUEST, APPLE MAPS etc.,

Table- I: Function of Traffic Control Apps

\begin{tabular}{|l|l|l|l|l|}
\hline WAZE & $\begin{array}{l}\text { GOOGLE } \\
\text { MAP }\end{array}$ & INRIX & $\begin{array}{l}\text { APPLE } \\
\text { MAPS }\end{array}$ & MAPQUEST \\
\hline It is free & It is free & It is free & It is free & It is free \\
\hline $\begin{array}{l}\text { real-time } \\
\text { traffic } \\
\text { information } \\
\text { is given }\end{array}$ & $\begin{array}{l}\text { Offers } \\
\text { real-time } \\
\text { traffic and } \\
\text { navigation } \\
\text { information. }\end{array}$ & $\begin{array}{l}\text { Keeps track } \\
\text { of your } \\
\text { routes and } \\
\text { driving } \\
\text { habits and } \\
\text { calculates } \\
\text { accordingly. }\end{array}$ & $\begin{array}{l}\text { Tells you the } \\
\text { fastest way } \\
\text { to get to } \\
\text { your } \\
\text { expected } \\
\text { destinations } \\
\text { based on }\end{array}$ & $\begin{array}{l}\text { It gives the } \\
\text { traffic real } \\
\text { time } \\
\text { information } \\
\text { and } \\
\text { alternative } \\
\text { routes if }\end{array}$ \\
\hline
\end{tabular}

\begin{tabular}{|c|c|c|c|c|}
\hline & & & $\begin{array}{l}\text { traffic, } \\
\text { location, } \\
\text { time of day, } \\
\text { and your } \\
\text { schedule. }\end{array}$ & necessary. \\
\hline $\begin{array}{l}\text { possible to } \\
\text { avoid } \\
\text { trouble } \\
\text { spots on } \\
\text { move }\end{array}$ & $\begin{array}{l}\text { Gives ETAs } \\
\text { and traffic } \\
\text { conditions. }\end{array}$ & $\begin{array}{l}\text { Users can } \\
\text { file incidents } \\
\text { like } \\
\text { accidents } \\
\text { and other } \\
\text { road } \\
\text { hazards. }\end{array}$ & $\begin{array}{l}\text { Gives you } \\
\text { guidance on } \\
\text { what lane } \\
\text { you should } \\
\text { be in based } \\
\text { totally on } \\
\text { traffic and } \\
\text { wherein } \\
\text { you're } \\
\text { going. }\end{array}$ & $\begin{array}{l}\text { Can see } \\
\text { traffic } \\
\text { issues both } \\
\text { in the map } \\
\text { and in } \\
\text { webcams. }\end{array}$ \\
\hline \multirow[t]{2}{*}{$\begin{array}{l}\text { sharing } \\
\text { route } \\
\text { information } \\
\text { with friends } \\
\text { and family }\end{array}$} & $\begin{array}{l}\text { Offers } \\
\text { automatic } \\
\text { rerouting } \\
\text { due to } \\
\text { traffic, } \\
\text { accidents, or } \\
\text { other road } \\
\text { conditions. }\end{array}$ & $\begin{array}{l}\text { Gives } \\
\text { indicators } \\
\text { for site } \\
\text { visitors } \\
\text { conditions, } \\
\text { lane } \\
\text { closures, } \\
\text { closed roads, } \\
\text { and } \\
\text { accidents. } \\
\end{array}$ & $\begin{array}{l}\text { It shows the } \\
\text { factors in } \\
\text { real-time } \\
\text { traffic } \\
\text { information. }\end{array}$ & $\begin{array}{l}\text { It has Live } \\
\text { traffic } \\
\text { camera } \\
\text { features to } \\
\text { view how } \\
\text { many cars } \\
\text { are on the } \\
\text { road. }\end{array}$ \\
\hline & & $\begin{array}{l}\text { Can also } \\
\text { search for } \\
\text { parking } \\
\text { options. }\end{array}$ & & $\begin{array}{l}\text { The "traffic } \\
\text { bar" with } \\
\text { coloured } \\
\text { feature at } \\
\text { the top of } \\
\text { the page } \\
\text { shows route } \\
\text { progress } \\
\text { and traffic } \\
\text { flow. }\end{array}$ \\
\hline
\end{tabular}

\section{B. Travel App}

This mobile app helps you to find the best restaurants in India or any other country where you are at that time and helps to learn about bus network and critique-including tour guide. Applications for mobile travel are perfect if you plan a vacation and help you book tickets at low rates. Travel apps allow you to book your trips and receive additional hotel and flight services and discounts. Make My Trip, Trip Advisor, Go Ibibio are the examples.

Table- II: Function Comparison of Travel Apps

\begin{tabular}{|l|l|l|l|}
\hline \multirow{2}{*}{$\begin{array}{l}\text { TRIP } \\
\text { RDVISO }\end{array}$} & $\begin{array}{l}\text { About APP one of } \\
\text { traveller's } \\
\text { maximum } \\
\text { complete online } \\
\text { sources, with } \\
\text { background } \\
\text { information on } \\
\text { severa towns and } \\
\text { regions, plus } \\
\text { highlights of what } \\
\text { to look and do }\end{array}$ & $\begin{array}{l}\text { Works on } \\
\text { at } \\
\text { and activities } \\
\text { written with the aid } \\
\text { of TripAdvisor } \\
\text { community } \\
\text { members, as } \\
\text { properly as pictures } \\
\text { and movies of their } \\
\text { travels so that you } \\
\text { know what to } \\
\text { anticipate earlier } \\
\text { than you arrive. }\end{array}$ & $\begin{array}{l}\text { Advantages } \\
\text { relationships } \\
\text { with a couple of } \\
\text { reservation sites, } \\
\text { which means } \\
\text { you can easily } \\
\text { reserve them } \\
\text { when you have } \\
\text { started } \\
\text { researching } \\
\text { hotels or } \\
\text { restaurants. }\end{array}$ \\
\hline $\begin{array}{l}\text { Google } \\
\text { Maps }\end{array}$ & $\begin{array}{l}\text { My number one } \\
\text { go-to travel app is } \\
\text { Google Maps. }\end{array}$ & $\begin{array}{l}\text { It makes your } \\
\text { journey plans form } \\
\text { up by means of the } \\
\text { map to put together } \\
\text { a plan for the day by } \\
\text { using journeying } \\
\text { places which are } \\
\text { grouped together. }\end{array}$ & $\begin{array}{l}\text { You also can } \\
\text { save your maps } \\
\text { offline so that } \\
\text { you won't } \\
\text { wander off even } \\
\text { if you do not } \\
\text { have } \\
\text { information for } \\
\text { your phone }\end{array}$ \\
\hline
\end{tabular}

Published By: 


\begin{tabular}{|c|c|c|c|}
\hline iExit & $\begin{array}{l}\text { It is one of best } \\
\text { traveller's with } \\
\text { background } \\
\text { information on } \\
\text { numerous cities } \\
\text { and regions, plus } \\
\text { highlights of what } \\
\text { to see and do. }\end{array}$ & $\begin{array}{l}\text { IExit tells you } \\
\text { precisely what is } \\
\text { near every toll road } \\
\text { exit, from gas } \\
\text { stations to ATMs. }\end{array}$ & $\begin{array}{l}\text { If there's a } \\
\text { particular } \\
\text { restaurant chain } \\
\text { or other service } \\
\text { you love, you } \\
\text { can mark it as a } \\
\text { favorite and the } \\
\text { app tells you if } \\
\text { it's coming up } \\
\text { on your route. }\end{array}$ \\
\hline UBER & $\begin{array}{l}\text { Uber operates } \\
\text { worldwide, and } \\
\text { while the in-app } \\
\text { options vary from } \\
\text { place to place, } \\
\text { everywhere the } \\
\text { overall concept is } \\
\text { the same. }\end{array}$ & $\begin{array}{l}\text { It has reviews of } \\
\text { hotels, restaurants, } \\
\text { and activities } \\
\text { written by } \\
\text { community } \\
\text { members, as well as } \\
\text { images and videos } \\
\text { of their travels so } \\
\text { you know what to } \\
\text { expect before you } \\
\text { arrive. }\end{array}$ & $\begin{array}{l}\text { First, the need to } \\
\text { carry local } \\
\text { currency is } \\
\text { eliminated. } \\
\text { Second, to get to } \\
\text { where you need } \\
\text { to go, you don't } \\
\text { have to speak } \\
\text { the same } \\
\text { language as } \\
\text { your driver. } \\
\text { Third, haggling } \\
\text { is not going on. }\end{array}$ \\
\hline Golbibo & $\begin{array}{l}\text { Goibibo is India's } \\
\text { largest hotels } \\
\text { aggregation and } \\
\text { also one of the } \\
\text { leading air } \\
\text { aggregators. }\end{array}$ & $\begin{array}{l}\text { The core value is } \\
\text { the differentiation } \\
\text { of its delivery of the } \\
\text { fastest and the most } \\
\text { trusted and reliable } \\
\text { user experiences. }\end{array}$ & $\begin{array}{l}\text { Goibibo is the } \\
\text { number one } \\
\text { ranked mobile } \\
\text { app under the } \\
\text { tour category. }\end{array}$ \\
\hline
\end{tabular}

\section{MANAGEMENT OF ACCIDENT VICTIMS}

The importance of the "Golden Hour" should be highlighted for both the users of the vehicle and the community in providing enough treatment to the victim of the accident in saving the injured. Medical care / first aid services should be provided on highways and busy roads, as well as ambulances and trained medical workers should be provided for delivering and transporting the injured person to nearby hospitals for treatment. The mobile apps are there with the facilities of automatic detection of car collision and notification for their critical time to protect them by their services in right time.

Table- III: Function Comparison of Accident Victim

\begin{tabular}{|c|c|c|c|}
\hline \multicolumn{4}{|c|}{ Apps } \\
\hline $\begin{array}{l}\text { NAME } \\
\text { OF } \\
\text { APP }\end{array}$ & $\begin{array}{l}\text { ABOUT } \\
\text { APP }\end{array}$ & $\begin{array}{l}\text { WORKING } \\
\text { NATURE }\end{array}$ & $\begin{array}{l}\text { ADVANTA-G } \\
\text { ES }\end{array}$ \\
\hline $\begin{array}{l}\text { SoSmart } \\
\text { App }\end{array}$ & $\begin{array}{l}\text { SOSmart } \\
\text { detects car } \\
\text { accidents } \\
\text { using your } \\
\text { smartphone's } \\
\text { internal } \\
\text { sensors and } \\
\text { sends an } \\
\text { emergency } \\
\text { notice to your } \\
\text { pre-selected } \\
\text { emergency } \\
\text { contacts with } \\
\text { your location. }\end{array}$ & $\begin{array}{l}\text { It gives its } \\
\text { service both in } \\
\text { manual mode or } \\
\text { automatic mode. }\end{array}$ & $\begin{array}{l}\text { 1.No matter what } \\
\text { your emergency } \\
\text { contacts are doing, } \\
\text { SOSmart will start a } \\
\text { loud alarm which will } \\
\text { call their attention. } \\
\text { 2. SOSmart no matter } \\
\text { where in the world } \\
\text { you are, will show } \\
\text { you a list of nearby } \\
\text { hospitals and show } \\
\text { you directions to get } \\
\text { there as quick as } \\
\text { possible. }\end{array}$ \\
\hline SoSafe Go & $\begin{array}{l}\text { Report an } \\
\text { incident or ask } \\
\text { for help in an } \\
\text { emergency }\end{array}$ & $\begin{array}{l}\text { It will Inform } \\
\text { your neighbours } \\
\text { if you are in an } \\
\text { emergency or } \\
\text { report if you } \\
\text { witness facts that } \\
\text { compromise the } \\
\text { safety of your } \\
\text { neighbourhood. }\end{array}$ & $\begin{array}{l}\text { 1.Operators with } \\
\text { emergency services } \\
\text { will inform you when } \\
\text { the reports have been } \\
\text { addressed and } \\
\text { successfully resolved. } \\
\text { 2. SOSafe GO will } \\
\text { guide responders to } \\
\text { the nearest hospital } \\
\text { from emergency }\end{array}$ \\
\hline
\end{tabular}

\begin{tabular}{|c|c|c|c|}
\hline & & & $\begin{array}{l}\text { locations by utilizing } \\
\text { Google Places and } \\
\text { Google Directions } \\
\text { App. }\end{array}$ \\
\hline Firebase & $\begin{array}{l}\text { 1. Firebase } \\
\text { provides a real } \\
\text { time database } \\
\text { and backend as } \\
\text { a service. } \\
\text { 2. The API } \\
\text { service } \\
\text { provided by } \\
\text { this app that } \\
\text { allows } \\
\text { application } \\
\text { data to be } \\
\text { synchronized } \\
\text { across clients } \\
\text { and stored on } \\
\text { Firebase's } \\
\text { cloud. }\end{array}$ & $\begin{array}{l}\text { It is a mobile } \\
\text { platform that } \\
\text { helps you } \\
\text { quickly develop } \\
\text { high-quality } \\
\text { apps, grow your } \\
\text { user base, and } \\
\text { earn more } \\
\text { money. Firebase } \\
\text { consists of } \\
\text { several features } \\
\text { that you can } \\
\text { mix-and-match } \\
\text { to fit your needs. }\end{array}$ & $\begin{array}{l}\text { 1.This app allows the } \\
\text { developers to } \\
\text { efficiently deploy web } \\
\text { apps and static } \\
\text { content to a Network. } \\
2 \text {. Storage: This } \\
\text { storage facility is } \\
\text { another best } \\
\text { advantage } \\
\text { Firebase. } \\
\text { 3. It is very useful } \\
\text { when you want to } \\
\text { create an app for } \\
\text { storing and serving } \\
\text { files of users such and } \\
\text { images and videos. }\end{array}$ \\
\hline
\end{tabular}

\section{CONCLUSION}

Science is the biggest collective effort. It has a specific role and several functions for our society's benefit: creating new awareness, improving education, and enhancing the quality of our lives. Science needs to address societal needs and international problems. Most beneficial innovation of science is cell phones. For many people around the world, cell phones have become a necessity. Just a few of the reasons for the increasing importance of cell phones are the ability to keep in contact with friends, business associates, and access to email. One of the main threats for the human mankind is the road accidents. Road traffic injury takes the lives of nearly 1.3 million people annually and 20-50 million people worldwide are injured at the same time. million people globally. In this digitized world we should have an awareness to use the smartphones with smartness. We should know how to utilize these essential apps for our daily routines for fruitful effects. We hope this will give a clear idea about the mobile applications and its availabilities for the public protections both in their time and their life.

\section{REFERENCES}

1. https://en.wikipedia.org/wiki/Traffic_accidents_in_India.

2. Peden MM, World report on road traffic injury prevention: WHO; 2004. 217. 3

3. Global status report on road safety 2015: supporting a decade of action. WHO; 2015.

4. Saving_millions_lives, WHO_en .pdf.

5. Gopalakrishnan S. A Public Health Perspective of Road Traffic Accidents. J Fam Med Prim Care. 2012;1(2):144.

6. Risk factors for road traffic injuries, Training manual.

7. Road accidents in India 2016. Government of India, Ministry of road transport \& highways transport research wing, New Delhi, www.morth.nic.in

8. Sharma SM. Road Traffic Accidents in India. Int J Adv Integ Med Sci 2016; 1(2): 57-64

9. Downing AJ, Baguley CJ, Hills BL. Road safety in developing countries: an overview. In: PTRC. Nineteenth Transport, Highwaiys and Planning Summer Annual Meeting. Proceedings of Seminar C, University of Sussex, 9-13 September 1991. London: PTRC Education and Research Services Ltd.

10. Jacobs GD, Sayer IA, Downing AJ. A preliminary study of road-user behaviour in developing countries. Transport and Road Research Laboratory. TRRL SR 646 Monograph. Crowthorne RG11 6AU, Berkshire, England, 1981. 
11. Jacobs GD, Sayer ZA. Road accidents in developing countries- Urban problems and remedial measures: Transport and Road Research Laboratory, Crowthorne, Berkshire. TRRL Supplementary Report 839: Crowthorne, 1984 (Transport and Road Research laboratory).

12. Verma A, Velumurugan S, Chakrabarty N, Srinivas S. Recommendations for driver licensing and traffic law enforcement in India aiming to improve road safety. Current Science. 2011;100(9):1373-85.

13. Steg L, van Brussel A. Accidents, aberrant behaviours, and speeding of young moped riders. Transportation Research Part F: Traffic Psychology and Behaviour. 2009;12(6):503-11

14. Mohammed Najeeb PM. A study of the psychological factors that influence the rule violation behaviour of drivers. 2017. 